\title{
SUBURBANIZACJA PO LÓDZKU NA PRZYKŁADZIE STAREJ GADKI ZLOKALIZOWANEJ W STREFIE PODMIEJSKIEJ LODZI
}

\author{
SUBURBANIZATION IN ŁÓDŹ FASHION (A CASE STUDY \\ OF STARA GADKA LOCATED IN THE SUBURBAN AREA OF LÓDŹ)
}

\begin{abstract}
NR DOI: $10.25167 / \mathrm{sm} 2018.032 .06 \quad$ s. $85-98$
ABSTRAKT: W dobie przemian funkcjonalno-przestrzennych w większości współczesnych wsi warto bliżej zbadać zachodzące w nich procesy. Celem artykułu jest identyfikacja przestrzennych aspektów suburbanizacji na przykładzie studium przypadku Starej Gadki. Ma on za zadanie ukazanie z poziomu sołectwa podobieństw występujących zjawisk w zależności od cech geograficznych. W pracy ukazano wieloetapowe przemiany przestrzenne w sołectwie, które stanowi przykład wsi leżącej w aglomeracji łódzkiej i bezpośrednio przylegającej do Łodzi. Pod wpływem dużego miasta wsie ulegają przemianom, a następnie zostają przez nie wchłonięte. Dzięki takim procesom Łódź, podobnie jak inne miasta, zwiększa swoją powierzchnię. Przeprowadzone badania inwentaryzacji wykazały, że Stara Gadka znajduje się w fazie wchłaniania i w niedalekiej przyszłości może się stać częścią Łodzi.
\end{abstract}

SŁOWA KLUCZOWE: wieś, suburbanizacja, przemiany przestrzenne, Łódź, Stara Gadka

ABSTRACT: In the era of functional and spatial changes going on in most contemporary villages, it is worth examining the processes taking place in them. The aim of the article is to identify the spatial aspects of suburbanization, based on the case study of Stara Gadka. The task is to show the similarities of occurring phenomena in dependence of geographic features perceived from the level of the village. The work presents multi-stage spatial changes in the village, which is an example of a village located in the Łódź agglomeration and directly adjacent to Łódź. Under the influence of a big city, the villages are transformed and then they are absorbed by the cities. Thanks to such processes, Łódź, like other cities, increases its area. The conducted inventory research showed that Stara Gadka is in the absorption phase and may become a part of Łódź in the near future.

KEY WORDS: village, suburbanization, spatial transformations, Lódź, Stara Gadka

\section{Wprowadzenie}

Miasta polskie znajdują się obecnie w fazie suburbanizacji, czyli przenoszenia form przestrzennych oraz sposobu życia miejskiego poza miasto centralne na obszary z nim

\footnotetext{
" Uniwersytet Łódzki, Wydział Nauk Geograficznych, Instytut Geografii Miast i Turyzmu, Katedra Geografii Miast, e-mail: malgorzata.rejter@unilodz.eu
} 
sąsiadujące, oraz w postępującym procesie zespalania suburbiów z miastem centralnym (Harańczyk 2015, s. 86). Suburbanizacja najintensywniej obejmuje obszary wokół dużych aglomeracji (jednak także współczesne suburbia powstają wokół średnich i małych miast polskich (Kajdanek 2009, s. 23; 2012, s. 9). Sposób i tempo rozwoju strefy podmiejskiej są cechami indywidualnymi, leżącymi w gestii władz gminnych, a najbardziej w rękach samych zainteresowanych zamieszkaniem z dala od centrum miasta. Przedmieścia stają się coraz chętniej wykorzystywanymi miejscami nie tylko do zamieszkania, ale także do powstawania nowych miejsc pracy. W artykule ukazany został proces przemian wsi podmiejskiej na przykładzie Starej Gadki położonej w suburban zone Łodzi i bezpośrednio z nią graniczącej (ryc. 1). Zachodzące w tej wsi charakterystyczne przemiany przestrzenno-ekonomiczne ukazują obraz wielu współczesnych suburbiów

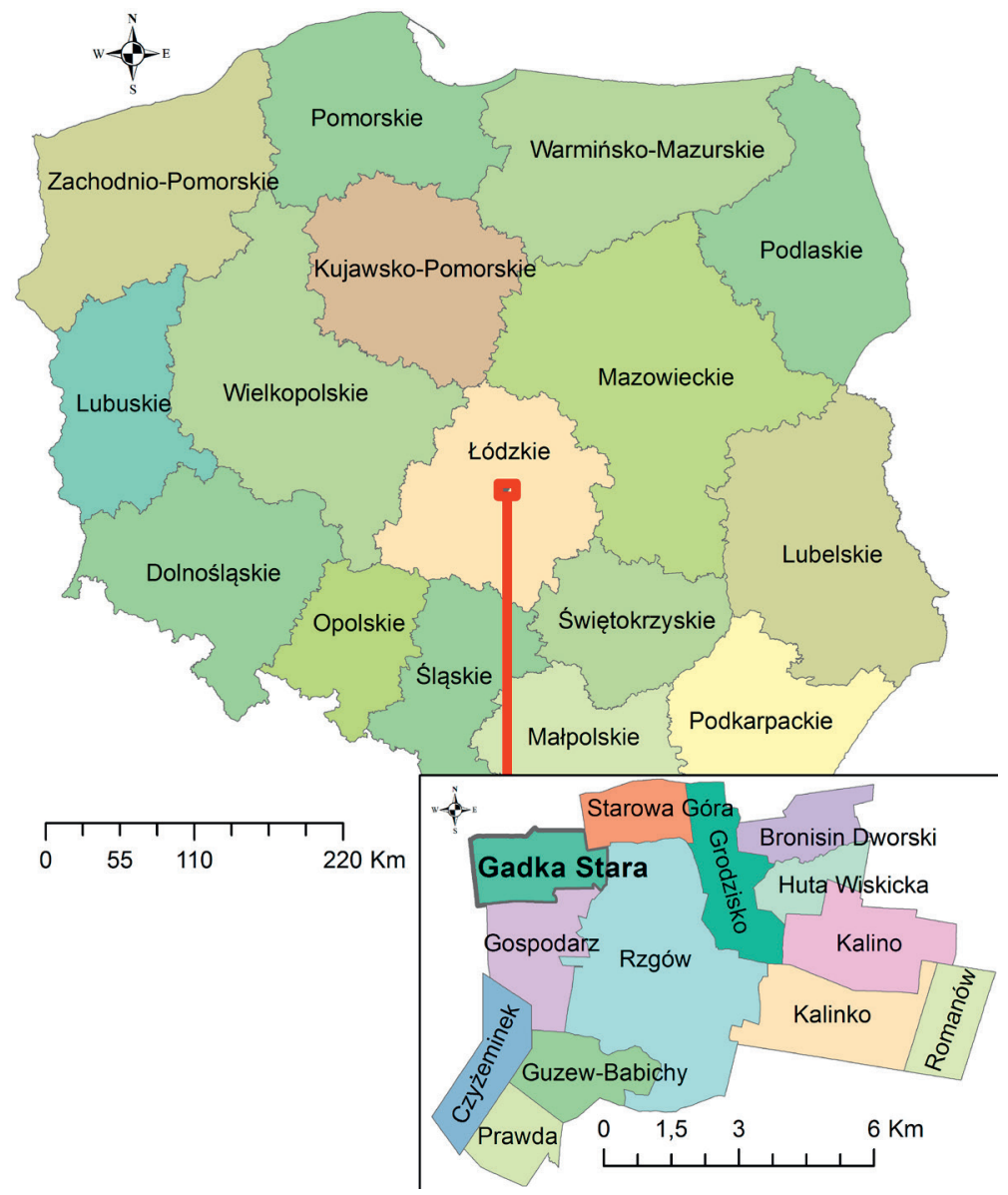

Ryc. 1. Położenie administracyjne Starej Gadki w gminie Rzgów w powiecie łódzkim wschodnim w województwie łódzkim na tle Polski

Źródło: Rejter 2015, s. 13. 
polskich. Rozwijają się one głównie ze względu na możliwość zakupu tańszej ziemi na wsi (Wdowicka 2008, s. 29). Wynikają też z mody na wiejskość, ale przede wszystkim z dążeń ludzi do szukania swojego miejsca na ziemi oraz kreatywności w rozwijaniu własnej działalności gospodarczej. Poszukiwania mieszkania i pracy, połączone nierozerwalnym węzłem najistotniejszych potrzeb człowieka, stają się motorem napędowym migracji z miast na wieś i przyczyniają się do przemian przestrzenno-funkcjonalnych terenów podmiejskich. Przemiany te prowadzą do urbanizacji wsi poprzez jej wielofunkcyjny rozwój, czyli semiurbanizację (Heffner 2011, s. 29).

Celem opracowania jest identyfikacja przestrzennych aspektów suburbanizacji na przykładzie studium przypadku Starej Gadki, mająca za zadanie ukazanie, z poziomu sołectwa, podobieństwa i różnice zjawisk występujących w zależności od cech geograficznych.

\section{Przegląd literatury}

O przemianach wsi polskich, zbliżonych do zaprezentowanych w artykule, pisano wielokrotnie w literaturze naukowej, m.in. w pracach: Jakóbczyk-Gryszkiewicz (1991; 1998; 2010); Wójcika (2006a; 2006b; 2008; 2013); Beima (2009); Kajdanek (2009; 2012); Bagińskiego (2011); Kacprzak, Staszewskiej (2011); Heffnera (2011); Szczygielskiego (2011); Brzezińskiego (2011); Gałki, Warych-Juras (2011) i wielu innych. Z faktu tak dużego zainteresowania badaczy wynika, że suburbanizacja w Polsce jest istotną fazą urbanizacji. To postępujące zjawisko warte jest cyklicznego badania. Różnice, jakie występują w procesie przemian, mają charakter regionalny i zależą od specyfiki danego regionu. Zjawisko suburbanizacji w strefie podmiejskiej przybiera kształt rozlewania się miasta, przez co dochodzi do zacierania się jego granic z terenami sąsiednich obszarów wiejskich. Zjawisko to zostało nazwane przez amerykańskich badaczy urban sprawl (Maciejuk 2015, s. 142). Postrzegane są różne konteksty tego zjawiska - począwszy od definiowania nim procesów przyczyniających się do ekspansji miasta, przez określanie zmian prowadzących do spadku gęstości zaludnienia w centralnych dzielnicach miasta, aż po zdecentralizowanie miasta, gdzie rola centrum przeniesiona jest na przedmieścia. Urban sprawl określany jest jako nowy wzorzec modelu przestrzennego przedmieść, który ignoruje historyczne uwarunkowania specyfiki miast. Wokół polskich miast obserwuje się powstawanie osiedli o zabudowie mieszkaniowej, tworzenie się parków biznesowych czy centrów handlowych (Beim 2009, s. 37-38). Urban sprawl przybiera formę nieciągłej, żywiołowej urbanizacji strefy podmiejskiej i oceniane jest przez wielu autorów jako zjawisko niekorzystne. J. Słodczyk zaobserwował zamienne stosowanie przez niektórych autorów pojęć urban sprawl $i$ „suburbanizacja” do określania tego samego zjawiska (Słodczyk 2012, s. 428).

W literaturze przedmiotu podkreśla się, że ujęcie kontinuum miejsko-wiejskiego nie tylko ma wymiar przestrzenny, na osi miejskość-wiejskość, lecz także niesie odpowiednią informację zawartą w procesach urbanizacji i modernizacji, którym to kontinuum podlega. 
Wyróżnia się dwa pojęcia urbanizacji: urbanizację w szerokim znaczeniu - odnoszoną do wsi i osiedli zurbanizowanych - oraz urbanizację w ścisłym znaczeniu, przypisaną do miast i semimiast, czyli okolicy półwiejskiej, prawie miasta o charakterze mieszanym (Sokołowski 1999).

Dla wyróżnienia urbanizacji obszarów wiejskich w literaturze stosuje się określenia "semiurbanizacja”, „suburbanizacja” i „deruralizacja” w odniesieniu do stref podmiejskich. Termin „deruralizacja” oznacza utratę rolniczego charakteru wsi na skutek urbanizacji (Jakóbczyk-Gryszkiewicz 2010, s. 10; Turzyński 2014, s. 41).

Suburbanizacja uznawana jest za jedną z najbardziej charakterystycznych cech urbanizacji po drugiej wojnie światowej. W jej wyniku następuje rozwój obszarów podmiejskich (Słodczyk 2012, s. 428). Do literatury pojęcie „semiurbanizacja” wprowadził S. Golachowski w wyniku obserwacji procesów urbanizacyjnych na obrzeżach miast (Golachowski 1965, s. 56). Semiurbanizacja to częściowa urbanizacja wsi, obejmująca proces zaawansowanych zmian funkcji rolniczych na pozarolnicze zmierzający w kierunku umiastowienia wsi, w efekcie czego wsie stają się semimiastami (Mikołajewicz 1971, s. 260; 1973, s. 10; Rajman 1990, s. 33). Suburbanizacja stanowi jedną z faz rozwoju miast, która polega na wyludnianiu się centrum i rozwoju strefy podmiejskiej. Jest to zjawisko złożone i wielowymiarowe, ale ogólnie polegające na rozszerzaniu miejskości poza granice miasta, co z czasem prowadzi do formalnego włączania zajmowanych obszarów do miast. Zjawiska suburbanizacyjne występują we wszystkich strefach podmiejskich większych miast, a ich największa intensywność występuje w gminach wiejskich sąsiadujących z miastami centralnymi oraz położonych wzdłuż głównych tras komunikacyjnych (Heffner 2016).

Najintensywniejszy etap rozwoju procesów suburbanizacyjnych w Polsce nastąpił po roku 1989. Wtedy to transformacja ustrojowa zaczęła wpływać na przeobrażanie form osadnictwa i wykształcanie nowych przestrzeni miast i obszarów podmiejskich. Uwidaczniało się to poprzez zmiany funkcjonalno-społeczne w obszarach wielkomiejskich i na mniejszą skalę wokół miast średnich i mniejszych (Zborowski, Raźniak 2013, s. 37-38).

Badania przeprowadzane w podłódzkich gminach wykazują zachodzenie tam intensywnych procesów suburbanizacyjnych, które w tym przypadku związane są z umiejscowieniem gmin przy ważnych szlakach komunikacyjnych łączących je z Łodzią (Brzeziński 2010, s. 176). Głównym powodem procesu suburbanizacji jest wzrost zamożności części społeczeństwa, a co za tym idzie - alokacja środków pieniężnych w wiejskie domy. Proces zachodzący na terenach podmiejskich często postrzegany jest negatywnie, jako anektowanie terenów rolniczych i nieużytków na tereny pod budownictwo mieszkaniowe. Ludzie, chcąc być bliżej natury, dzikiej fauny i flory, chętnie przeprowadzają się z miast na obszary podmiejskie. Na skutek tego zniszczeniu ulegają obszary będące ostoją dzikiej zwierzyny i tereny będące cennymi zasobami naturalnymi i krajobrazowymi (Brzeziński 2010, s. 170; 2011, s. 188).

Niedoskonałość ustawy o planowaniu przestrzennym powoduje nieuporządkowany przyrost osiedli podmiejskich na wsiach. Dochodzi do przekwalifikowywania użytków 
rolnych na tereny przeznaczone pod budownictwo. Niekorzystnym efektem tego jest podział dużych obszarów na mniejsze, nierównej wielkości działki, na których powstają indywidualne, różnorodne projekty domów, stwarzające chaos przestrzenny (Zathey 2003, s. 242; Śleszyński 2014, s. 21).

\section{Geneza i historyczny rozwój Starej Gadki}

W 1496 r. Gadka zajmowała obszar około 24 ha. W roku 1827 liczyła tylko 20 domów o łącznej powierzchni $179 \mathrm{~m}^{2}$, natomiast w roku 1879 liczba domów we wsi wzrosła do 62, a ich powierzchnia wynosiła $406 \mathrm{~m}^{2}$ (Słownik geograficzny...).

Mapa Królestwa Polskiego pochodząca z 1843 r. ukazuje zabudowany obszar skoncentrowany w bezpośrednim sąsiedztwie rzeki Ner, na jej lewym brzegu, wzdłuż obecnej południowej granicy sołectwa. Natomiast mapa topograficzna z lat 80. XX w. (ryc. 2) pokazuje strukturę przestrzenną zbliżoną do współczesnej. Układ przestrzenny Starej Gadki ma dawną formę wsi ulicówki, która przejawia się w ciasno skoncentrowanej po obu stronach ulicy zabudowie mieszkaniowej. Obecny rozwój wsi ukierunkowuje ją w stronę wielodrożnicy (Koter, Liszewski, Suliborski 1999).

Przez środek Starej Gadki przepływa z południa na północ rzeka Ner. Równolegle do doliny rzecznej biegną główne ulice sołectwa. Po jej wschodniej stronie znajdują się: Czartoryskiego, Kombajnowa i Zdrojowa, od zachodu przebiegają ulice Lucerniana i Ogrodników, a pomiędzy nimi znajdują się pola uprawne i łąki. W pierwotnym układzie przestrzennym każdy gospodarz za swoją zagrodą miał pasmo pola uprawnego. Obecnie, w związku ze zmianami własnościowymi gruntów, pozostało jedynie kilku rolników, którzy uprawiają rolę odkupioną od innych starogadczan. Przy ul. Ogrodników zabudowania rozmieszczone są w sposób rozproszony, a przy ul. Lucernianej w większości w sposób zwarty z długimi pasmami pól uprawnych lub łąk za domem. Co kilka działek występuje pas wolny od zabudowy, przeznaczony najczęściej na łąkę lub nieużytek, umożliwiający dojazd do pola uprawnego. Układ przestrzenny Starej Gadki ma charakter trwalszy niż same pola, które ulegają nieustannym przeobrażeniom i zmianom funkcji użytkowej.

Fragmentarycznie możemy zaobserwować dawny charakter wsi w postaci zachowanej zabudowy zagrodowej. Stara Gadka jest przykładem wsi, które przez całe lata ulegały i nadal ulegają ciągłym przemianom przestrzennym. Podlegają zanikowi rozłogi wiejskie i pola uprawne. Głównym powodem tego jest rozdrabnianie gospodarstw na skutek podziałów rodzinnych. Powstają coraz to mniejsze działki, co wraz ze zmianą sposobu użytkowania gruntu nadaje wsi wygląd zbliżony do podmiejskiego. Również przemiany ekonomiczne powodują ciągłą zmianę morfologii wsi. Okres świetności Starej Gadki jako lidera produkcji rolnej przypadł na lata 80. XX w. Ten okres dawno już minął, a nastąpił czas transformacji wsi w kierunku usług i produkcji odzieżowej. Podobne procesy zachodzą np. na Śląsku Opolskim, gdzie funkcję rolniczą wypiera funkcja mieszkaniowa dodatkowo wspierana przez lokalizację zakładów przemysłowych na wsiach (Heffner 2011, s. 19). 


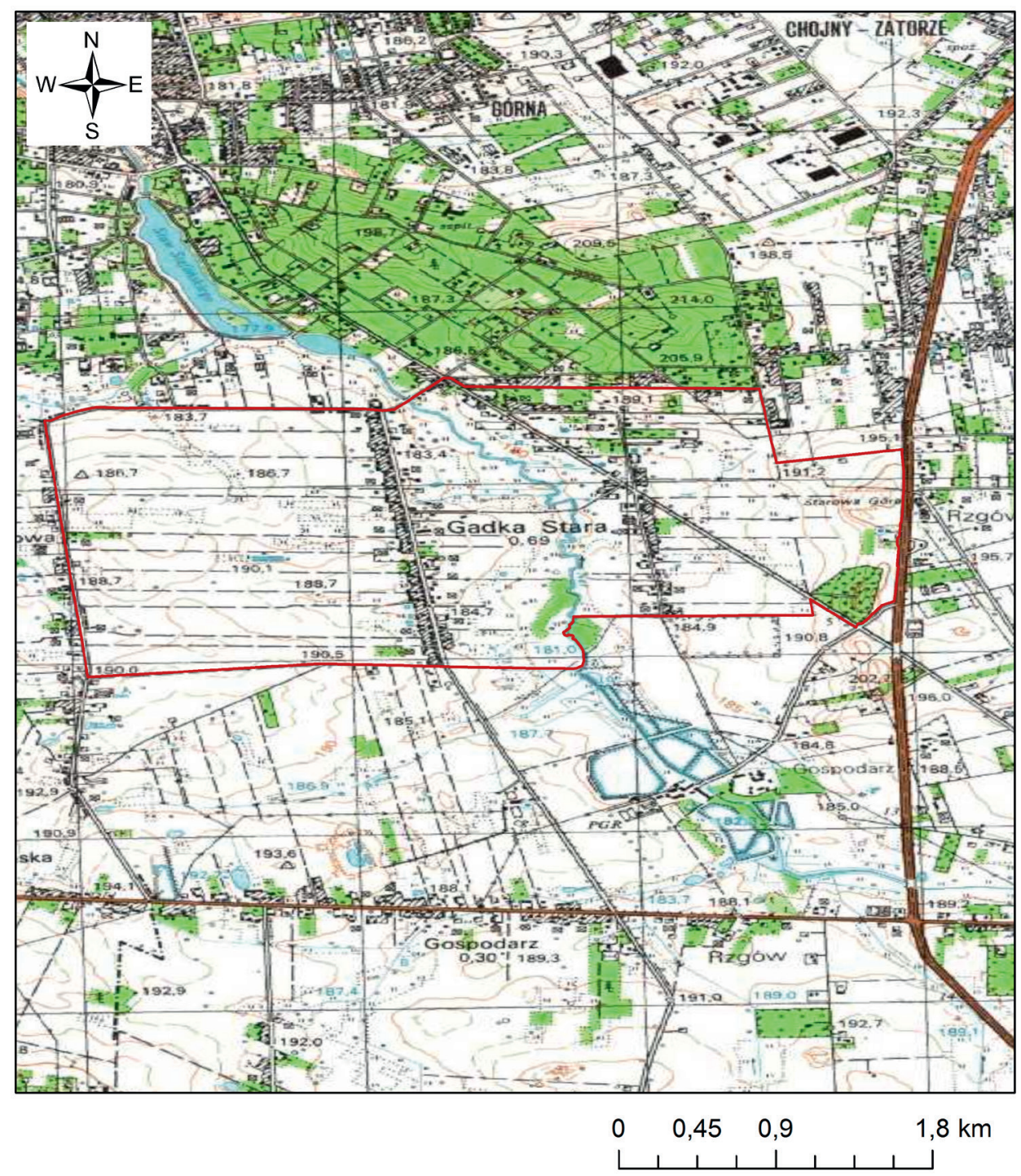

Ryc. 2. Mapa topograficzna Starej Gadki w latach 80. XX w.

Źródło: http://geoportal.gov.pl/dane/skany-map-topograficznych.

\section{Struktura funkcjonalno-przestrzenna Starej Gadki}

Sołectwo zajmuje 4,1134 km², co stanowi 6\% powierzchni gminy Rzgów $\left(66 \mathrm{~km}^{2}\right)$. W roku 2011 w sołectwie mieszkało 738 osób, było to 8\% mieszkańców całej gminy Rzgów (9 tys.). Ludność na terenie sołectwa koncentruje się w jego centralnej i północno-wschodniej części. Średnia gęstość zaludnienia dla Starej Gadki to 
179 osób/km², przy średniej gęstości zaludnienia dla całej gminy Rzgów 144 osoby/ $\mathrm{km}^{2}$. Obszar ten można uznać za miejski na podstawie stosowanego w Unii Europejskiej (Raport o rozwoju... 2000) kryterium delimitacji obszarów wiejskich, jakim jest gęstość zaludnienia, który wyznaczono na 100 osób $/ \mathrm{km}^{2}$.

Według oceny charakterystyki typów funkcjonalnych obszarów wiejskich Stara Gadka ma obszary, które uczestniczą w procesach rozwojowych. Ich cechami są:

- położenie w zasięgu silnego oddziaływania ośrodków miejskich,

- specjalizacja w zakresie funkcji pozarolniczych zintegrowanych z ośrodkiem miejskim,

- dojazdy do pracy w mieście,

- dobry dostęp do usług publicznych,

- dobra dostępność komunikacyjna miasta,

- bliska strefa zaplecza rolniczego (Wójcik 2013).

Tereny słabo zagospodarowane Starej Gadki zajmują ponad 80\% powierzchni, jest to ok. 332 ha. Na obszary te składają się: łąki (153 ha), nieużytki (97 ha) oraz grunty orne (82 ha). W sposób intensywny pod tereny zabudowane (65 ha) wykorzystywane jest ok. 16\%, a na cele komunalne 3,16\% sołectwa (Rejter 2015, s. 61).

W związku z przemianami przestrzenno-funkcjonalnymi charakterystycznymi nie tylko dla Starej Gadki, ale dla wielu podmiejskich wsi architektura budynków występująca na terenie sołectwa jest zróżnicowana. Określa się taki stan rzeczy jako „rozchwiany”. Tworzą go przemieszane: zabudowa zagrodowa, zabudowa produkcyjno-usługowa oraz zabudowa typu rezydencjonalnego. Taka fizjonomia wsi potwierdza zanik funkcji rolniczej na jej obszarze. Podobne zmiany występują także na innych obszarach wiejskich w Polsce. Tradycyjne budownictwo wiejskie typu zagrodowego zanika na rzecz budownictwa typowo miejskiego (Czarnecki 2009, s. 77; Bagiński 2011, s. 12-13). Powstaje nowe budownictwo, które wskazuje na wzrost poziomu zamożności mieszkańców. O fizjonomii zabudowy sołectwa decydują formy charakteryzujące suburbia otaczające wielkie miasta. Istotnym elementem zróżnicowania fizjonomii wsi jest sposób włączania nowego budownictwa mieszkaniowego w jej strukturę przestrzenną. Działki, na których znajdują się domy mieszkalne, mają zróżnicowaną wielkość - od 0,04 ha do prawie 2 ha. Cechą charakteryzującą fizjonomię Starej Gadki jest zabudowa mieszana. Rozwój wsi w kierunku zabudowy podmiejskiej ułatwia fakt, iż wieś ta graniczy z Łodzią i jest usytuowana w strefie aglomeracji łódzkiej. Architektura domów znajdujących się przed granicą Starej Gadki, należących do Łodzi, niczym nie różni się od tych znajdujących się na terenie wsi. Fizjonomia jest jednak inna. Tworzy ją zabudowa o charakterze mieszkaniowym oraz usługowo-produkcyjnym. Na terenie Starej Gadki w większości występują zabudowania jednorodzinne, w tym te wyróżniające się charakterem rezydencjonalnym (ryc. 3). Rezydencje najczęściej cechuje usytuowanie z dala od ulicy, mają dwuspadowe dachy i otynkowane elewacje. Najczęściej są to budynki 1-2 piętrowe.

Potwierdzeniem tego, że we wsi zanika funkcja rolnicza, jest fakt występowania zabudowy zagrodowej w niewielkim stopniu (ryc. 4). Koncentruje się głównie wzdłuż ulic 


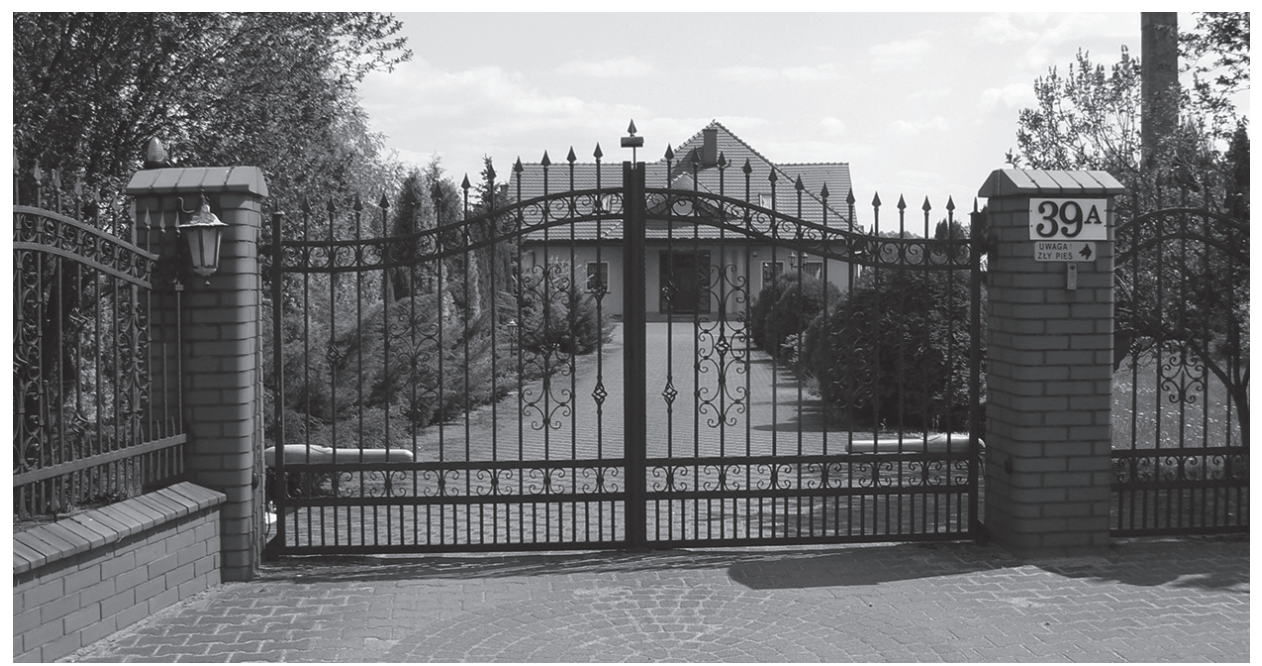

Ryc. 3. Zabudowa rezydencjonalna

Fot. M. Rejter.

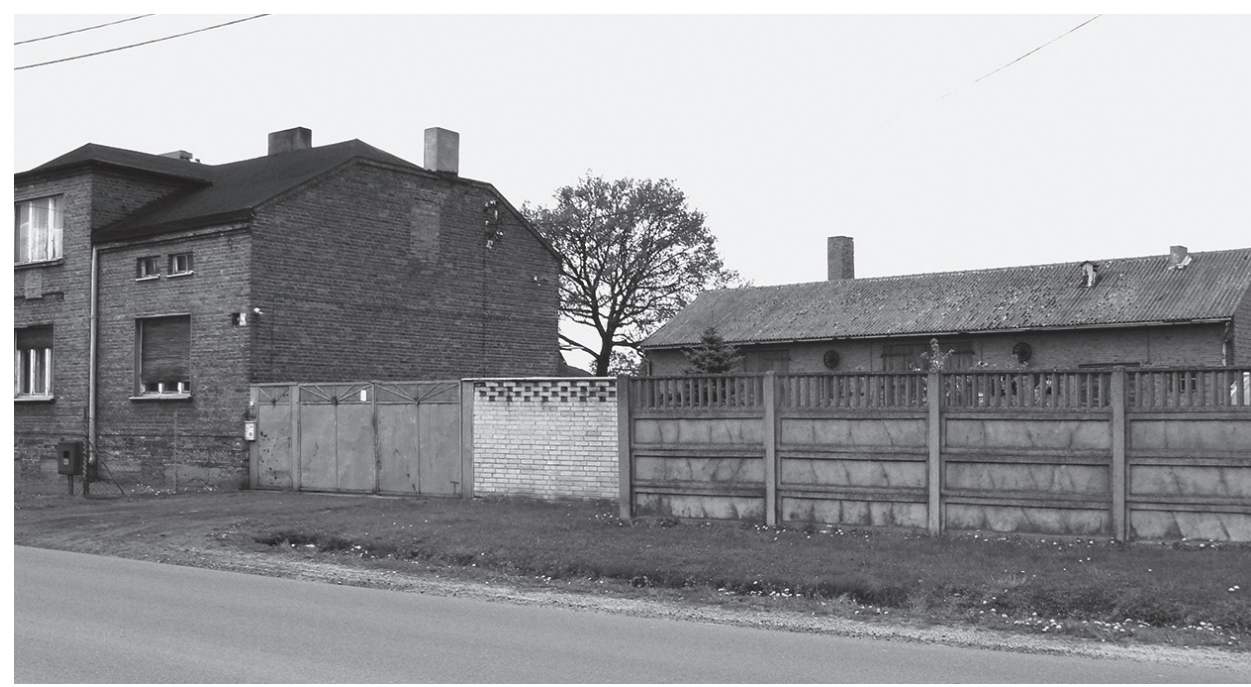

Ryc. 4. Zabudowa zagrodowa

Fot. M. Rejter.

Lucernianej i Kombajnowej. Są to z reguły budynki parterowe lub jednopiętrowe, często nieotynkowane, $\mathrm{z}$ dachem dwuspadowym. Budynkom tym towarzyszą zabudowania pełniące funkcje rolnicze, służące do przechowywania ciągników i płodów rolnych.

Stara Gadka jest wsią zadbaną, a domostwa i przylegające do nich tereny są uporządkowane. Na szerokich działkach budynki mieszkalne usytuowane są kalenicą 
równolegle do ulicy. Jeżeli działka jest wystarczająco duża, to nowe budynki znajdują się w znacznym oddaleniu od szlaku komunikacyjnego. Zwykle domy zwrócone są wejściem do drogi, mają szerokie podjazdy i ogrodzenia otwarte. Działki często wyposażone są w garaże, a budynkom mieszkalnym towarzyszą przydomowe miejsca zabawowo-rekreacyjne dla dzieci i miejsca wypoczynku dla dorosłych. W przypadku starszej zabudowy, głównie zagrodowej, gdy budynek usytuowany jest kalenicą równolegle do drogi, wejście do niego znajduje się od strony podwórka. Najczęściej występują ogrodzenia pełne, ale też, w mniejszym stopniu, ogrodzenia otwarte. Niekiedy zmiana własnościowa działek, zwłaszcza tych z zabudową zagrodową, pociąga za sobą potrzebę renowacji domów mieszkalnych przez nowych właścicieli. Działania renowacyjne upodabniają zabudowę do nowoczesnej. Równocześnie dochodzi do degradacji pozostałych, niewykorzystywanych budynków gospodarczych na posesjach. Na obszarze Starej Gadki występują m.in. budynki w formie prostopadłościanu, proste w swojej konstrukcji, ale z zadbanymi elewacjami i drewnianymi ogrodzeniami. W przypadku wąskiej działki budynki usytuowane są kalenicą prostopadle do ulicy. Taki kształt był typowy dla domów jednorodzinnych budowanych w latach 60. i 70. XX w. Nowo budowane domy mają wejście od strony drogi. Do starszych natomiast wchodzi się od strony podwórka, od frontu znajduje się ogródek. Budynki cechuje małe zróżnicowanie pod względem użytego materiału wykończeniowego. Prawie 93\% budynków w sołectwie jest zbudowanych z cegieł, tylko niektóre z nich mają elewację otynkowaną, a ok. 4\% - elewację z sidingu. Niespełna $2 \%$ budynków wykonanych jest z drewna i zlokalizowane są one głównie przy ul. Zdrojowej. Niewiele ponad $1 \%$ zbudowano z blachy i w większości wykorzystywane są na działalność gospodarczą.

Podsumowując typy zabudowy w Starej Gadce, widzimy występowanie zróżnicowania w tym zakresie. Prawie 65\% budynków to domy jednorodzinne. Spośród nich możemy wyróżnić proste budynki jednorodzinne i zabudowania rezydencjonalne. Natomiast $1 / 3$ całej zabudowy to budynki zagrodowe, po części przekształcone i wykorzystywane na potrzeby usługowo-produkcyjne. Najmniejszy odsetek (5\%) zajmują zabudowania typu gospodarczego. W większości jest to nowa zabudowa, przeznaczona na cele gospodarcze.

Na terenie Starej Gadki dominującą formą zabudowy jest nowe budownictwo jednorodzinne, przy jednoczesnej zanikającej formie budownictwa zagrodowego, co ma związek z zanikiem rolnictwa na rzecz działalności pozarolniczej. Zabudowa taka koncentruje się wzdłuż ulic: Lucernianej, Laskowej, Usługowej i Zagrodowej. Domy jednorodzinne są zróżnicowane. Występują typowe „wielkomiejskie wille” umiejscowione na niedużych działkach oraz rezydencje znajdujące się na dużych działkach.

Najwięcej budynków pełni funkcję mieszkaniową (73\%). Wśród pełniących funkcje usługowe (18\%) występują te związane z handlem (8\%), w tym ze sprzedażą bezpośrednią na terenie sołectwa, typu sklepy spożywcze czy sprzedaż owoców, warzyw i kwiatów. Ponadto występuje też funkcja związana z ochroną zdrowia oraz pozostałymi usługami, m.in. zakłady fryzjerskie czy kosmetyczne. Znajdują się one w wydzielonej części domu mieszkalnego, z przeznaczeniem specjalnie na wykonywanie działalności. 
Podczas inwentaryzacji budynków, która odbyła się w 2015 r., wykazano należycie urządzoną przestrzeń wiejską. Domy mieszkalne w większości były w bardzo dobrym i dobrym stanie technicznym (78\%). W przestrzeni wsi było kilka zaniedbanych, niewykorzystywanych już gospodarstw rolnych (3\%). Nie przeszły one renowacji ani zmiany funkcji z rolnej na usługową i do dziś pozostają w niezmienionym kształcie mimo braku wykorzystywania ich do funkcji rolnej.

\section{Działalność rolnicza mieszkańców Starej Gadki}

Cała gmina Rzgów w okresie ostatnich 30 lat przeszła ogromne przemiany w strukturze funkcjonalnej. Do 1988 r. funkcją dominującą było rolnictwo, od roku 2000 dominuje funkcja pozarolnicza (Wójcik 2006b).

Czynniki wpływające na rozwój rolnictwa w Starej Gadce to głównie najlepsze gleby w gminie i długi okres wegetacyjny, który wynosi 235 dni w roku. Natomiast do obecnych czynników wpływających na zanik funkcji rolniczej można zaliczyć: spadek opłacalności produkcji płodów rolnych, zmniejszanie wielkości gospodarstw rolnych oraz sprzedaż pól uprawnych. Wszystkie wymienione elementy wpływają na niskie zyski osiągane z działalności rolniczej. Wymusza to na rolnikach poszukiwanie dodatkowych źródeł dochodu w działalnościach pozarolniczych.

Inwentaryzacja w terenie i rozmowy odbyte z mieszkańcami Starej Gadki pozwoliły uzyskać wyraźny obraz tego sołectwa. Na obszarze wsi, dawniej o profilu rolniczo-ogrodniczym, dochodzi do przemian. Aktualnie rolniczą działalność prowadzi jedynie pięciu gospodarzy. Zamieszkują oni tradycyjne gospodarstwa zagrodowe wraz z przylegającymi do nich polami uprawnymi. Głównymi gatunkami, jakie uprawiają, są zboża - pszenica, jęczmień, rzepak. Gospodarstwa zajmują duże obszary wraz ze szklarniami i tunelami foliowymi, które umiejscowione są między ulicami Lucernianą a Ogrodniczą. Uprawiane są w nich sezonowo ogórki, sałata oraz rośliny ozdobne. W latach 80. XX w. region ten zasłynął jako enklawa najbogatszych „badylarzy”.

Należy podkreślić, że większość działek w sołectwie uległa rozdrobnieniu i zmianie użytkowania ziemi z rolniczej na mieszkalno-usługowo-produkcyjną. Średnia wielkość gospodarstw rolnych w Starej Gadce w 1990 r. wynosiła 3-6 ha, w 2003 r. spadła poniżej 3 ha (Wójcik 2008). Badania terenowe przeprowadzone przez autorkę w 2015 r. potwierdzają tę postępującą tendencję (Rejter 2015, s. 67).

\section{Działalność pozarolnicza mieszkańców Starej Gadki}

Zarówno w Polsce, jak i w innych krajach UE podstawowymi jednostkami na terenach wiejskich są małe firmy, które odgrywają decydującą rolę w gospodarce (Kłodziński 2000, s. 41).

Starą Gadkę charakteryzuje bardzo wysoki poziom zatrudnienia pozarolniczego oraz zróżnicowanie prowadzonych działalności gospodarczych. Działalności te zaspokajają potrzeby lokalne i pozalokalne. Obecnie Stara Gadka stanowi doskonały przykład bo- 
gatej wielofunkcyjnej wsi, w której przechodzenie z głównej funkcji rolniczej na pozarolniczą następuje dzięki przedsiębiorczości jej rezydentów. Około 10\% mieszkańców założyło działalności gospodarcze, w większości będące firmami usługowymi. Stara Gadka jest małym sołectwem, z niezbyt dużą liczbą mieszkańców (738 osób w 2011 r.), z czego 10\% zajmowało się działalnością gospodarczą usługową i produkcyjną. $\mathrm{Na}$ stronie Centralnej Ewidencji i Informacji o Działalności Gospodarczej według stanu na dzień 14 marca 2015 r. zarejestrowanych było 75 działalności gospodarczych, w tym 69 aktywnych.

W Starej Gadce struktura podmiotów gospodarczych jest zróżnicowana. Najczęściej występują przedsiębiorstwa z zakresu usług, które zajmują 66\% ogólnej struktury (45), ale poza nimi zlokalizowane są firmy związane z funkcją przemysłową, zajmujące $17 \%$ (12), a także z zakresu budownictwa 13\% (9) oraz transportu 4\% (3).

Spośród podmiotów usługowych najwięcej reprezentuje handel hurtowy, w mniejszym stopniu detaliczny. Wśród działalności produkcyjnych prym wiodą przedsiębiorstwa produkujące odzież, choć występują także firmy wytwarzające konstrukcje metalowe oraz części do pojazdów silnikowych. Z kolei w sekcji budownictwa występują zakłady wykonujące konstrukcje i pokrycia dachowe, stolarkę budowlaną, prowadzące rozbiórkę i usługi burzenia obiektów budowlanych oraz wykonujące instalacje elektryczne. Natomiast sekcję transportu reprezentują firmy realizujące głównie transport drogowy towarów.

Według Europejskiej Klasyfikacji Działalności (EKD) w Starej Gadce występują następujące sekcje:

- produkcja (18\%),

- budownictwo (13\%),

- usługi dla producentów, w tym: transport, pośrednictwo finansowe i obsługa nieruchomości (20\%),

- usługi dla konsumentów, materialne, w tym handel i naprawy (44\%),

- usługi dla konsumentów, niematerialne, w tym edukacja i ochrona zdrowia (5\%).

Podsumowując, można powiedzieć, że działalność mieszkańców omawianej wsi przyczynia się do zmian w sferze przestrzennej i funkcjonalnej sołectwa. Uwidacznia się to we wzroście firm mających nierolniczy charakter. Podobne procesy występują również w innych rejonach Polski (Brzeziński 2011, s. 195).

\section{Czym jest obecnie Stara Gadka?}

Stara Gadka stanowi przykład wsi, w której życie nie jest już mocno autonomiczne i wyizolowane. Tkwi ona w układzie społeczeństwa globalnego i podlega ciągłym przemianom zachodzącym w całym kraju. Te dokonujące się metamorfozy nie są obojętne dla wsi ani dla rolnictwa (Jacher 1995).

Ważnym aspektem do przemyśleń i analiz przemian zachodzących w suburbiach jest fakt, czy omawiana wieś jest jeszcze wsią czy już przechodzi w fazę semimiasta. Argumenty, iż Stara Gadka, podobnie jak wiele innych polskich wsi, wkracza w fazę 
semimiasta, to: we wsi następuje rozdrobnienie gospodarstw rolnych oraz przekazywanie gruntów rolnych niewielu osobom pozostającym w rolnictwie, następują podziały gospodarstw na cele nierolnicze i odchodzenie od zajęć rolniczych. Dochodzi też do dwuzawodowości dzięki powstawaniu nowych zakładów przemysłowych i usługowych na terenie wsi. Przyczynia się to do dominacji funkcji pozarolniczych i wymieszania funkcji rolniczych z pozarolniczymi. W związku z tym Starą Gadkę zamieszkuje przeważająca liczba osób pracujących w pozarolniczej działalności (Sokołowski 1999; Heffner 2011, s. 23). Prowadzi to do dezagraryzacji, deruraryzacji, czyli do urbanizacji wsi. Śmiałą hipotezę wysunął E. Bagiński, uznając, że w przyszłości nie będzie podziału na miasto i wieś, a miasto będzie wszędzie (Bagiński 2011, s. 14).

Stara Gadka zmienia się na skutek postępującej dominacji funkcji przemysłowych i usługowych, przechodząc w fazę semiurbanizacji. Zjawisko to jest typowe dla większości współczesnych obszarów wiejskich w Polsce (Koter, Liszewski, Suliborski 1999).

Badana wieś jest przykładem miejscowości, w której procesy urbanizacji przestrzennej, społecznej i ekonomicznej prowadzą do zmniejszania się różnic w poziomie życia pomiędzy miastem a wsią. Przyczyną tego są przemiany społeczno-gospodarcze, które stymulują wizualne przemiany, czyli gentryfikację wsi wynikającą z postępującej różnorodności stylów życia mieszkańców, a co za tym idzie - kształtowanie się nowej jakości społeczno-kulturowej. Ulegają przemianom tradycyjne struktury wiejskie ukształtowane w modelu rolno-produkcyjnym. Wymienione procesy prowadzą do poszerzania się strefy podmiejskiej Łodzi poprzez wchłanianie okolicznych obszarów (Wójcik 2013).

\section{Podsumowanie. Suburbanizacja po łódzku a suburbanizacja po polsku - podobieństwa i różnice}

Proces suburbanizacji w Polsce został spowodowany poprzez niewystarczającą i o złej jakości tkankę mieszkaniową w miastach, której niedobory skłaniają zamożniejszą ludność do szukania lepszego bytu na terenach podmiejskich (Kajdanek 2012, s. 222). Suburbia okolic Łodzi, podobnie jak innych polskich miast, odgrywają przede wszystkim rolę obszarów rezydencjonalnych, służących jako sypialnie i ewentualne miejsca spędzania czasu w dni wolne od pracy, ale też jako miejsca pracy czy korzystania z usług (Kajdanek 2012; Zborowski, Raźniak 2013; Rejter 2015). W fizjonomii zabudowy Starej Gadki możemy wydzielić część starszą, zagrodową, i część nową, rezydencjonalną. Oprócz podobieństw suburbanizacji łódzkiej do ogólnokrajowej występują między nimi również różnice. Na przykładzie omawianej wsi możemy zaobserwować wysoki udział zatrudnienia w sektorze usług, co w innych regionach Polski, np. w województwie opolskim, nie występuje mimo atrakcyjnych lokalizacji (Heffner 2011, s. 30). Miasta macierzyste, wokół których powstają suburbia, odnoszą różnorakie korzyści w wyniku powiększania swojego obszaru oraz terenów komunikacyjnych, usługowych, komunalnych, rekreacyjnych, mieszkaniowych i przemysłowych. Również i suburbia przechodzą transformacje: zanikają nierentowne tradycyjne gospodarstwa rolne, powstaje możliwość pracy w zawodach pozarolniczych, stara zabudowa zagrodowa jest 
sukcesywnie zastępowana nowymi domami jednorodzinnymi typu podmiejskiego oraz letniskowego, ulega poprawa zaopatrzenia w wodociąg, kanalizację czy gazociąg (Jakóbczyk-Gryszkiewicz 1998, s. 77-78). Przemiany przestrzenno-gospodarcze przyczyniają się do stale zachodzących procesów urbanizacyjnych wielu wsi, w tym i Starej Gadki. Powoli zanika i przekształca się tradycyjne osadnictwo rolnicze, ustępując miejskim wzorcom życia. Podsumowując: suburbanizację po łódzku pod wieloma aspektami można wpisać w suburbanizację po polsku.

\section{Bibliografia}

Bagiński E., 2011, Suburbanizacja - nieunikniona przyszłość osadnictwa?, „Studia Miejskie” t. 3.

Beim M., 2009, Modelowanie procesu suburbanizacji w aglomeracji poznańskiej, Bogucki Wydawnictwo Naukowe, Poznań.

Brzeziński C., 2010, Procesy suburbanizacji obszarów podmiejskich na przykładzie gmin powiatu pabianickiego. Zmiany przestrzenne, „Acta Universitatis Lodziensis. Folia Oeconomica” 245.

Brzeziński C., 2011, Suburbanizacja przestrzenna i ekonomiczna terenów podmiejskich Łodzi na przykładzie gmin powiatu zgierskiego, „Studia Miejskie” t. 3.

Czarnecki A., 2009, Rola urbanizacji w wielofunkcyjnym rozwoju obszarów wiejskich, Instytut Rozwoju Wsi i Rolnictwa Polskiej Akademii Nauk, Warszawa.

Gałka J., Warych-Juras A., 2011, Regionalne uwarunkowania suburbanizacji w Polsce, „Studia Miejskie” t. 3. Golachowski S., 1965, Proces semiurbanizacji w województwie opolskim, „Kwartalnik Opolski” nr 2.

Harańczyk A., 2015, Procesy suburbanizacji w krakowskim obszarze funkcjonalnym, „Studia Miejskie” t. 18.

Heffner K., 2011, Semiurbanizacja a suburbanizacja. Ewolucja procesów w aglomeracji opolskiej, „Studia Miejskie" t. 3.

Heffner K., 2016, Proces suburbanizacji a polityka miejska w Polsce, https://www.researchgate.net/publication/303901294_Proces_suburbanizacji_a_polityka_miejska_w_Polsce (dostęp 29 listopada 2018).

Jacher W., 1995, Wieś a restrukturyzacja, [w:] Starosta P. (red.), Zbiorowość terytorialna i więzi społeczne, Wydawnictwo Uniwersytetu Łódzkiego, Łódź.

Jakóbczyk-Gryszkiewicz J., 1991, Zróżnicowanie urbanizacji wsi w strefie podmiejskiej Łodzi, „Acta Universitatis Lodziensis. Folia Geographica" No 13.

Jakóbczyk-Gryszkiewicz J., 1998, Przeobrażenia strefpodmiejskich dużych miast. Studium porównawcze strefy podmiejskiej Warszawy, Łodzi i Krakowa, Wydawnictwo Uniwersytetu Łódzkiego, Łódź.

Jakóbczyk-Gryszkiewicz J., 2010, Przemiany funkcjonalne w regionie miejskim Łodzi, [w:] Dynamika iskutki procesów urbanizacji w regionach miejskich po 1990 roku na przykładzie regionu miejskiego Łodzi, Wydawnictwo Uniwersytetu Łódzkiego, Łódź.

Kacprzak E., Staszewska S., 2011, Wptyw suburbanizacji na wiejskie struktury osadnicze, „Studia Miejskie” t. 3 .

Kajdanek K., 2009, Rozwój strefy podmiejskiej Wroctawia w perspektywie socjologii miasta - społeczna charakterystyka przestrzeni podmiejskich, [w:] Jażdżewska I. (red.), Strefa podmiejska i małe miasta w okresie transformacji. XXII Konwersatorium Wiedzy o Mieście, Wydawnictwo Uniwersytetu Łódzkiego, Łódź.

Kajdanek K., 2012, Suburbanizacja po polsku, Nomos, Kraków.

Kłodziński M., 2000, Doświadczenia krajów członkowskich Unii Europejskiej w zakresie strategii wielofunkcyjnego rozwoju wsi, [w:] Stasiak A. (red.), Możliwości wielofunkcyjnego rozwoju wsi polskiej w kontekście integracji z Unia Europejska, PAN KPZK, Warszawa.

Koter M., Liszewski S., Suliborski A., 1999, Łódź i region Polski środkowej, Łódzkie Towarzystwo Naukowe, Łódź.

Maciejuk M., 2015, Suburbanizacja miast średniej wielkości w Polsce na przykładzie regionu jeleniogórskiego, „Studia Miejskie” t. 20.

Mikołajewicz Z., 1971, Obszary urbanizacji w województwie opolskim, [w:] Golachowski S. (red.), Struktury i procesy osadnicze, PWN, Opole-Wrocław. 
Mikołajewicz Z., 1973, Urbanizacja wsi w województwie opolskim, Instytut Śląski w Opolu, Opole.

Rajman J., 1990, Geografia osadnictwa i zaludnienia, Wydawnictwo Naukowe WSP, Kraków.

Raport o rozwoju społecznym Polska 2000. Rozwój obszarów wiejskich, 2000, Program Narodów Zjednoczonych ds. Rozwoju, Warszawa.

Rejter M., 2015, Jakość życia mieszkańców wsi na przykładzie Gadki Starej w gminie Rzgów, praca licencjacka, promotor A. Kulawiak, Łódź.

Słodczyk J., 2012, Historia planowania miast, Wydawnictwo Uniwersytetu Opolskiego, Opole.

Stownik geograficzny Królestwa Polskiego i innych krajów słowiańskich, t. 11, nakł. F. Sulimierskiego i W. Walewskiego, Warszawa, 1880-1914, http://dir.icm.edu.pl/pl/Slownik_geograficzny/Tom_XI/218 (dostęp 11 kwietnia 2015).

Sokołowski D., 1999, Zróżnicowanie zbioru małych miast $i$ większych osiedli wiejskich w Polsce w ujęciu koncepcji kontinuum wiejsko-miejskiego, Wydawnictwo Uniwersytetu Mikołaja Kopernika, Torun.

Szczygielski K., 2011, Proces suburbanizacji w strefie podmiejskiej Opola, „Studia Miejskie” t. 3.

Śleszyński P., 2014, Procesy suburbanizacji w Polsce a polityka przestrzenna i regionalna, [w:] Wolaniuk A. (red.), Centra i peryferie $w$ okresie transformacji ustrojowej. XXVII Konwersatorium Wiedzy o Mieście, Wydawnictwo Uniwersytetu Łódzkiego, Łódź.

Turzyński M., 2014, Gdzie kończy się miasto, a zaczyna wieś? Studium przypadku Gdańska i jego otoczenia, [w:] Wolaniuk A. (red.), Centra i peryferie w okresie transformacji ustrojowej. XXVII Konwersatorium Wiedzy o Mieście, Wydawnictwo Uniwersytetu Łódzkiego, Łódź.

Wdowicka M., 2008, Rola małych miast w kształtowaniu konkurencyjności obszarów metropolitalnych, [w:] Heffner K., Marszał T. (red.), Ośrodki lokalne w strefie oddziaływania wielkich miast, KPZK PAN, Warszawa. Biuletyn KPZK PAN z. 238.

Wójcik M., 2006a, Postrzeganie procesów transformacji przez mieszkańców wsi aglomeracji tódzkiej, [w:] Jewtuchowicz A., Suliborski A. (red.), Przestrzenne zróżnicowanie procesów transformacji społeczno-gospodarczej w regionie łódzkim, Wydawnictwo Uniwersytetu Łódzkiego, Łódź.

Wójcik M., 2006b, Przemiany gospodarcze na obszarach wiejskich aglomeracji łódzkiej (przykład pięciu gmin), [w:] Jewtuchowicz A., Suliborski A. (red.), Przestrzenne zróżnicowanie procesów transformacji społeczno-gospodarczej w regionie łódzkim, Wydawnictwo Uniwersytetu Łódzkiego, Łódź.

Wójcik M., 2008, Przemiany społeczno-gospodarcze wsi aglomeracji łódzkiej w okresie transformacji ustrojowej, Wydawnictwo Uniwersytetu Łódzkiego, Łódź.

Wójcik M., 2013, Przemiany społeczno-przestrzenne osiedli wiejskich, Wydawnictwo Uniwersytetu Łódzkiego, Łódź.

Zathey M., 2003, Wroctawska strefa suburbialna, [w:] Jażdżewska I. (red.), Funkcje metropolitalne $i$ ich rola w organizacji przestrzeni. XVI Konwersatorium Wiedzy o Mieście, Triada, Łódź.

Zborowski A., Raźniak P., 2013, Suburbanizacja rezydencjonalna w Polsce-ocena procesu, „Studia Miejskie” t. 9 .

http://geoportal.gov.pl/dane/skany-map-topograficznych (dostęp 11 kwietnia 2015). 